\title{
The Impact of Guided-Discovery-Learning Model on Students' Conceptual Understanding and Critical Thinking Skills
}

\section{1a*Muhali, ${ }^{2}$ Binar Kurnia Prahani, ${ }^{3}$ Husni Mubarok, ${ }^{1 a}$ Nova Kurnia, ${ }^{1 b}$ Muhammad Asy'ari}

\begin{abstract}
${ }^{1 a}$ Chemistry Education Department, bSport and Health Education Department, Universitas Pendidikan Mandalika. Jl. Pemuda No. 59A, Mataram, 83125, Indonesia

2Physics Department, Universitas Negeri Surabaya, Jl. Ketintang, Surabaya, 60231, Indonesia ${ }^{3}$ Graduate Institute of Digital Learning and Education, National Taiwan University of Science and Technology, Taipei, Taiwan
\end{abstract}

*Corresponding Author e-mail: muhali@undikma.ac.id

Received: September 2021; Revised: October 2021; Published: November 2021

\begin{abstract}
The current study describes how the guided-discovery-learning model impacts students' conceptual understanding (SCU) and students' critical thinking skills (SCTS) on the topic of solubility. The quasiexperimental research with a posttest-only nonequivalent control group design was used in this study. The experimental group (45 students) and the control group (47 students) were selected by the saturated sampling technique. Data on SCU was collected using an objective true false test instrument with correction/proofing, while data on critical thinking skills was collected using an essay test instrument. The research data were analyzed descriptively and statistically (Mann-Whitney U). The research found the SCU (mean= 81.51 vs. mean $=72.81$ ) and SCTS (mean= 70.46 vs. mean $=58.43$ ) in the experimental group was better than the control group, both descriptively and statistically $(\mathrm{p}<$ $0.05)$. These findings indicate that the guided-discovery-learning model significantly impacted SCU and SCTS on the solubility topic.
\end{abstract}

Keywords: guided-discovery-learning; conceptual understanding; critical thinking skills

How to Cite: Muhali, M., Prahani, B. K., Mubarok, H., Kurnia, N., \& Asy'ari, M. (2021). The Impact of Guided-Discovery-Learning Model on Students' Conceptual Understanding and Critical Thinking Skills. Jurnal Penelitian Dan Pengkajian Ilmu Pendidikan: E-Saintika, 5(3), 227-240. https://doi.org/10.36312/esaintika.v5i3.581

\section{INTRODUCTION}

Teaching scientific thinking skills has become a challenge in recent years (Schmaltz et al., 2017). Some students tend to trust intuition and subjectivity rather than objective scientific findings (Lilienfeld et al., 2012). This condition reflects a low of students' science conceptual understanding (Lay \& Osman, 2018), so that it is essential to improve it (Bisson et al., 2016). Conceptual understanding is defined as understanding the main principles and the relationship between these principles (O'Dwyer et al., 2015), which is indispensable in understanding science (Freire et al., 2019). It can be developed through learning process-oriented towards providing explicit conceptual problems (Crooks \& Alibali, 2014) to allow students to solve problems and discuss related concepts studied (Hiebert \& Grouws, 2007). Science and 
science learning generally involves (1) procedural knowledge related to applied laws, principles, and equations (Bisson et al., 2016), (2) conceptual knowledge related to conceptual understanding, relationships, and principles contained in science (RittleJohnson et al., 2015), and (3) conditional knowledge related to the ability to choose the knowledge that is relevant to the situation or problem faced (Muhali et al., 2019). Conceptual understanding in Bloom's taxonomy is defined as the ability to make connections between knowledge possessed and operate that it together (Anderson \& Krathwohl, 2001) and is believed to be an essential component in achieving student science learning outcomes, including in chemistry learning (Holme et al., 2015).

Chemistry learning requires three representation types: macroscopic, microscopic, and symbolic (Treagust et al., 2003). Therefore, chemistry learning is difficult because it includes a breadth of dimensions, such as epistemological, ontological, methodological, and axiological (Ribeiro \& Pereira, 2013). In addition, chemistry learning, which is considered irrelevant and uninteresting (Aikenhead, 2003), is also caused students to not interested in it. It was further explained that chemistry studies concrete and abstract things in one unit, causing some students to struggle with chemistry learning (Adnyana, 2012). The difficulty of learning chemistry mainly lies in understanding the submicroscopic aspects in explaining macroscopic phenomena and chemical symbols (Sudria et al., 2011). In line with this statement, the results of other studies show that students often have difficulty in microscopic material such as ionic covalent compounds, polar and non-polar compounds, ionic and molecular reactions, and oxidation number (Tsaparlis, 2018). These materials emphasize students to think abstractly (Lay \& Osman, 2018).

One of the chemistry materials studied by high school students is solubility and solubility products. Solubility and solubility products are some of the materials in abstract chemistry learning. This material is also filled with chemical formulas and reactions. It requires understanding all aspects, especially the microscopic and symbolic aspects, to make it easier to understand. Solubility and solubility products are always focused on microscopic aspects, such as the decomposition of compounds into ions, calculating the $\mathrm{pH}$ of a solution, and estimating the formation of precipitates based on solubility products quantitatively. In addition, to understand the concepts in the material solubility and solubility product, students must understand the basic concepts related to concentration, reaction equations, chemical equilibrium, solutes, and solvents so as not to experience difficulties in learning these materials.

In addition to the emphasis on conceptual understanding, 21st-century chemistry learning emphasizes aspects of critical thinking skills (Andayani et al., 2020; Muhali, 2019) that are claimed to be one of the main competencies in learning (T. A. Thomas, 2011; ŽivkoviL, 2016). Critical thinking is reflective thinking that focuses on deciding what to do or believe (Ennis, 2018). It was further explained that critical thinking is an intellectual discipline process that actively and skillfully conceptualizes, applies, analyzes, synthesizes, and evaluates information from observations, experiences, reflections, reasoning, or communication to guide beliefs and actions (Scriven \& Paul, 1987). The consensus results conducted by Facione (1990) concluded that critical thinking skills have six cognitive indicators, namely interpretation, analysis, inference, evaluation, explanation, and self-regulation. The importance of critical thinking skills as an academic output competency can be seen from the demands of school curricula in various countries (Arsal, 2017; NCATE, 2008), including Indonesia (Kemendikbud, 2018). However, students' SCTS (SCTS) tend to 
be low categorized (Arsal, 2017; Demirhan \& Köklükaya, 2014; Fitriani et al., 2019). The low of SCTS in chemistry learning often stem from difficulties in understanding terms, concepts, and the application of formulas (Muhali, 2021). The learning process that emphasizes problem-solving and increasing motivation by involving science process skills is essential to improve SCTS (Kwan \& Wong, 2015; Thaiposri \& Wannapiroon, 2015). One of the learning activities with the characteristics described and highly recommended for students' scientific literacy development (National Research Council, 2012) is inquiry-based learning (Arends, 2012; Preston et al., 2015; U. Sari \& Güven, 2013).

Guided discovery learning (GDL) is a learning model related to inquiry-based, problem-based, and constructivist learning (Großmann \& Wilde, 2019; Lee \& Yeung, 2021). The GDL model that guides students in the learning process is helpful for students with low learning outcomes (Kalyuga, 2013). The GDL model is defined as learning activities that systematically, critically, and logically find knowledge, attitudes, and skills independently (Janssen et al., 2014). The GDL model in this study has five stages, namely (1) simulation in the form of giving problems (Hmelo-Silver et al., 2007), which encourages students to think critically and read literature to find relevant knowledge to solve the problems given, (2) encourage students to identify problem-solving strategies based on information that has been learned from the literature (Arends, 2012; Hoy, 2013) to formulate problems and hypotheses, (3) conduct experiments (Eggen \& Kauchak, 2012), (4) evaluate students' conceptual understanding (SCU) by giving questions/related problems (Asy'ari, Ikhsan, et al., 2019; Muhali et al., 2019; Prayogi et al., 2018), and (5) draw conclusions regarding problem-solving based on data and information obtained during the discovery process (Arends, 2012; Asy'ari, Hidayat, et al., 2019; Muhali et al., 2019).

The results of previous studies have found a positive impact of the GDL model on SCU (Ayodele \& Nasiru, 2021; Muliyani, 2018; Shamsuddeen \& Amina, 2016) and SCTS (Suparini et al., 2020; Yuliani \& Saragih, 2015). However, no research has been found regarding the impact of the GDL model on SCU and SCTS in chemistry learning with solubility and solubility product subject matters. Based on the description, this study aimed to describe the effect of the GDL model on SCU and SCTS on solubility and solubility product subject matters. Conceptual understanding in this study is the students' ability to interpret and reconstruct their knowledge (Anderson \& Krathwohl, 2001). While critical thinking skills are students' cognitive abilities to analyze problems, make inferences, evaluate, and explain in detail (Ennis, 2011, 2018; Facione, 2020; Gelder, 2005) to solve problems based on the reflection of the learning activities carried out.

\section{METHOD}

This current study used a quasi-experimental with post-test-only control group design (Table 1) (Fraenkel et al., 2012). This study was conducted at one of the public senior high schools in Mataram City, Indonesia, with 92 students selected according to saturated sampling. The experimental and control groups were determined using the cluster random sampling technique. The experimental group (45 students) was taught using the GDL model $(X)$, while the control group (47 students) was taught using expository learning (-). Observations were made after the learning was carried out (01 and 02). 
Table 1. The research design of posttest only control group design

\begin{tabular}{lcc}
\hline Group & Treatment & Obsevation \\
\hline Experimental & $X$ & $0_{1}$ \\
\hline Control & - & $0_{2}$ \\
\hline
\end{tabular}

Data on SCU and SCTS were collected using test instruments. The conceptual understanding test instrument is a true-false objective test with ten items of correction and proof. Students are asked to choose the True (T) of False (F) option on the conceptual understanding test instrument. If the students choosed $\mathrm{T}$, they were then asked to prove the choice or statement. In contrast, if the students choosed F, they were then asked to correct the statement in the conceptual understanding test instrument item given. In contrast to the conceptual understanding test instrument, the SCTS test instrument in the form of a description of five items has been adjusted to the critical thinking skills indicator in this study (examples of the instrument items used in this study are presented in Table 2).

Table 2. Conceptual understanding and critical thinking skills instruments

Items Indicators

\section{Conceptual understanding instruments}

T-F: It is known that the solubility product (Ksp) of the compounds $\mathrm{AgCl}=10^{-10}, \mathrm{Ag} 2 \mathrm{CrO}_{4}=10^{-12}, \mathrm{AgI}=10^{-16}$, $\mathrm{Ag}_{2} \mathrm{~S}=10^{-4}$. Among these compounds, the most difficult to dissolve in water is Ag2S.

T-F: If $20 \mathrm{ml}$ of $0.01 \mathrm{M} \mathrm{AgNO3} 0.01 \mathrm{M}$ solution is mixed with $80 \mathrm{ml}$ of $0.02 \mathrm{M} \mathrm{K}_{2} \mathrm{CrO}_{4} 0.02 \mathrm{M}$, (Ksp Ag2 $\mathrm{CrO}_{4}=2.4 \mathrm{x}$ $\left.10^{-12}\right)$. Then in the mixing $\mathrm{Ag}_{2} \mathrm{CrO}_{4}$ precipitate formed because $\left[\mathrm{Ag}^{+}\right]^{2}\left[\mathrm{CrO}_{4}^{2-}\right]>\mathrm{Ksp} \mathrm{Ag}_{2} \mathrm{CrO}_{4}\left(6.4 \times 10^{-8}>2.4 \times\right.$ $\left.10^{-12}\right)$.

T-F: A total of $4.35 \mathrm{mg} \mathrm{Ag}_{2} \mathrm{CrO}_{4}$ can be dissolved in 100 $\mathrm{ml}$ of water. Then the solubility of $\mathrm{Ag}_{2} \mathrm{CrO}_{4}$ in $\mathrm{mol} \mathrm{L}^{-1}$ is $2.31 \times 10^{-4} \mathrm{~mol} \mathrm{~L}^{-1}$ where $\mathrm{Ar} \mathrm{O}=16 ; \mathrm{Cr}=52 ; \mathrm{Ag}=108$.
Make interpretations and reconstruct problemsolving by identifying, classifying, and applying facts, concepts, principles, and procedures.

\section{Critical thinking skills instruments}

A beaker containing $100 \mathrm{ml}$ of a saturated solution of magnesium fluoride $(\mathrm{MgF} 2)$ at a temperature of $18{ }^{\circ} \mathrm{C}$ is evaporated, and $7.6 \mathrm{mg}$ of solid $\mathrm{MgF} 2$ is obtained. What is the solubility product of $\mathrm{MgF} 2$ at $18{ }^{\circ} \mathrm{C}$ ? (Ar $\mathrm{Mg}=24 ; \mathrm{F}=$ 18) and explain how the effect of temperature on the determination of the solubility product?

Suppose the determination of the solubility product of $\mathrm{AgCl}=10^{10}$ in a $\mathrm{CaCl}_{2}$ solution with a concentration of 0.1 $\mathrm{M}$, the solubility of $\mathrm{AgCl}$ in a $\mathrm{CaCl}_{2}$ solution is $5 \times 10^{-10}$ Molar. Do you agree with the statement below? Why? Explain your answer with calculations!
Perform analysis, inference, evaluation, and explanation in detail. 


\section{Items}

Indicators

The solubility product constant for magnesium hydroxide $\left(\mathrm{Mg}(\mathrm{OH})_{2}\right)$ is $2 \times 10^{-12}$. If the $\mathrm{pH}$ of a solution of magnesium chloride $\left(\mathrm{MgCl}_{2}\right)$ with a concentration of $2 x$ $10^{-4} \mathrm{M}$ is increased, at what $\mathrm{pH}$ will precipitate begin to occur? What happens to the increase in $\mathrm{pH}$ due to the addition of the base? Explain!

The employed test instrument was validated by two validators (doctoral qualifications) using a validation sheet to review the content and the construct validity aspects (Nieveen, 1999). Determination of the validity of the research instrument using four rating scales with categories: score $>3.6=$ very valid, score 2.8-3.6 = valid, score 1.92.7 = less valid, and score 1.0-1.8 = invalid (Asy'ari, Hidayat, et al., 2019). The results of the instrument validation showed that the conceptual understanding test instrument (construct validity $=3.76$; content validity $=3.84$; reliability $=0.97$ ) and the SCTS test instrument (construct validity $=3.81$; content validity $=3.84$; reliability $=0.95$ ) were declared valid and reliable (Borich, 2016), hence was used to collect data.

The research data were analyzed descriptively using the equation [score $=($ score achieved/maximum score) x 100] (Asy'ari, Ikhsan, et al., 2019). The One-Sample Kolmogorov-Smirnov (K-S) and Levene tests were used to determine data normality and homogeneity before carrying out non-parametric statistical analysis using the MannWhitney U-test with the help of IBM SPSS Statistics 23 to determine the effect of the GDL model on SCU and SCTS.

\section{RESULTS AND DISCUSSION Students' initial knowledge}

Students' initial knowledge was obtained from test results on salt hydrolysis material. It was then used to identify differences between the experimental and control groups. The students' initial knowledge in the experimental and control groups was descriptively and statistically not significantly different $(p>0.05)$ (see Table 3), so it can be stated that these groups relatively have the same knowledge.

Table 3. The students' initial knowledge

\begin{tabular}{lccccc}
\hline \multicolumn{1}{c}{ Group } & $\mathbf{N}$ & Mean & K-S Sig. & Levene sig. & p \\
\hline Experimental & 45 & 62.91 & 0.200 & \multirow{2}{*}{0.577} & \multirow{2}{*}{0.985} \\
Control & 47 & 62.98 & 0.200 & & \\
\hline
\end{tabular}

\section{Students' conceptual understanding}

SCU data was measured after learning activities. The results showed that SCU in the experimental and control groups increased after learning. The basic difference between the two groups lies in achieving the conceptual understanding mean score, namely 81.51 for the experimental group and 72.81 for the control group. The result showed that this difference is due to differences in learning treatment, namely the GDL model (experimental group) and expository (control group) (see Table 4).

The normality test of the SCU data was first carried out using the K-S test as a prerequisite test before the parametric test was applied (Table 4). The analysis results showed that the experimental group data were normally distributed (sig. $>0.05$ ) while 
the control group data were not normally distributed (sig. $<0.05$ ), so that nonparametric statistical analysis using the Mann-Whitney U-test was carried out to determine the effect GDL model on the SCU.

Table 4. Students' conceptual understanding data distribution

\begin{tabular}{llcccc}
\hline \multicolumn{1}{c}{ Group } & N & Mean & Std. Deviation & Sig. & Normality \\
\hline Experimental & 45 & 81.51 & 11.45 & 0.200 & Yes \\
Control & 47 & 72.81 & 15.45 & 0.038 & No \\
\hline
\end{tabular}

The statistical test results also showed similar results compared to descriptive test results. The SCU was significantly different $(\mathrm{p}<0.05)$ between the experimental and control groups, whereas the experimental group that thought using the GDL model was better than the control group that thought using expository learning (Table $5)$.

Table 5. Mann-Whitney U-test result of students' conceptual understanding

\begin{tabular}{cccc}
\hline Item & $\mathbf{N}$ & $\mathbf{z}$ & $\mathbf{p}$ \\
\hline Post-test & 92 & -2.504 & 0.012
\end{tabular}

This study indicates that the GDL model significantly affects SCU on the solubility subject. A similar study also showed a significant effect of the GDL model on SCU (R. Y. Sari \& Cahyo, 2020) but on different learning materials compared to this study.

\section{Students' critical thinking skills}

SCTS in the experimental group were better than the control group in terms of the mean score (Table 6). SCTS mean score obtained on the experimental group was higher (mean score $=70.46$ ) than the control group mean score (mean score $=58.43$ ). So it can be stated that the GDL model was better than expository learning in improving SCTS.

The normality test of SCTS data was also carried out using the K-S test. SCTS data both in the experimental and control groups were not normally distributed (sig. $<0.05)$. The Mann-Whitney U-test's non-parametric statistics were then carried out to determine the GDL model's effect on SCTS.

Table 6. Students' critical thinking skills data distribution

\begin{tabular}{llcccc}
\hline \multicolumn{1}{c}{ Group } & N & Mean & Std. Deviation & Sig. & Normality \\
\hline Experimental & 45 & 70.46 & 10.46 & 0.000 & No \\
Control & 47 & 58.43 & 14.56 & 0.005 & No \\
\hline
\end{tabular}

The statistical test results showed that the GDL model had a significant effect ( $p$ $<0.05$ ) on SCTS on the solubility product and solubility product (see Table 7). In line with this study, the research that applied inquiry-based learning to physics learning found a significant increase in SCTS (Prayogi \& Verawati, 2020). Emphasis on the active role of students in inquiry-based learning (e.g., GDL model) is stated to be the core aspect of scientific thinking skills development (Arends, 2012; Asy'ari et al., 2021), including critical thinking (Suhirman et al., 2021). On the other hand, different results were found by Arsal (2017) that inquiry-based learning has not significantly affected 
SCTS. However, Arsal's findings focus on the affective domain of critical thinking (critical thinking disposition).

Table 7. Mann-Whitney U-test result of students' critical thinking skills

\begin{tabular}{cccc}
\hline Item & $\mathbf{N}$ & $\mathbf{z}$ & $\mathbf{p}$ \\
\hline Post-test & 92 & $-4,099$ & 0.000 \\
\hline
\end{tabular}

\section{Discussion}

SCU and SCTS in the experimental group reached an average of 81.51 and 70.46 respectively, while in the control group, it was 72.81 and 58.43. The results showed that SCU and SCTS taught using the GDL model were better $(p<0.05)$ than students taught by expository learning. Differences in SCU and SCTS in each group are caused by differences in treatment in the learning process. Inquiry-based learning, including the GDL model, requires students to learn through a series of scientific processes to formulate problems, make hypotheses, conduct experiments to collect data, process and analyze data, and draw conclusions (Kibirige \& Maake, 2021; Lee \& Yeung, 2021; Shieh \& Yu, 2016). Students can learn to find patterns in various concrete and abstract situations through this scientific process (Yerizon et al., 2018). These processes enable students to develop mastery of cognitive skills (Asy'ari, Fitriani, et al., 2019), such as SCU and SCTS (Arsal, 2017; Yuliani \& Saragih, 2015).

The results showed that the GDL model significantly affected SCU and SCTS (see Table 5 and Table 7). The GDL model closely relates to the understanding process and critical thinking skills related to students' mental construction and cognitive abstraction (Schunk, 2012). In contrast with the experimental group's results, the control group, which thought with exploratory learning, obtained the lower mean score of SCU and SCTS. The expository learning process that only emphasizes students' theoretical forms of concepts conveyed orally without looking at the macroscopic and microscopic forms of the solubility and solubility product material causes the low SCU and SCTS on chemistry in the control group. Lesson materials with oral communication delivery are effectively used to convey information and understanding but are not suitable for complex, detailed, and abstract materials (Cardellini, 2012). Learning that relies on teacher explanations is also claimed to burden students' cognitive (Trninic, 2018).

Theoretically, the GDL model is included in constructivist learning, which aims to develop rational thinking, critical thinking, deep conceptual understanding, and self-regulation (Moreno, 2010). The GDL model in this study emphasizes students' active process through group discussions and feedback. This process is carried out so that the internalization of knowledge into students' cognitive systems can be carried out. This emphasis is in line with social cognitive theory, which states that social activities in this study are group discussions are essential activities to develop students' thinking skills (Kwan \& Wong, 2015; Vygotsky, 1981). The GDL model provides opportunities for students to improve, expand, and apply their knowledge and skills in various activities. These activities help students to analyze thinking processes and integrate new conceptual knowledge gained through problem formulation, choosing problem-solving strategies, interpretation, explanation, evaluation, and reflection on learning (Murphy et al., 2021; van der Graaf et al., 2020). In addition, the intervention for internalizing knowledge to teach SCU and SCTS was also applied in this study. It is in line with the opinion that presenting a new problem or phenomenon can lead students to conduct a more in-depth study of a concept being 
studied or known as the internalization process (Muhali et al., 2019, 2020). In addition to group interaction, the experimental group's SCU and SCTS were taught through inquiry activities that allowed the students to choose problem-solving strategies and evaluate their knowledge. Attention to these activities is allegedly experiencing growth in the implementation of 21st-century learning (Fischer et al., 2014) because it was found to be effective in teaching higher-order thinking skills (e.g., critical thinking skills) (Furtak et al., 2012).

In line with the current study, some research has been found the effectiveness and/or positive effect of the GDL model on SCU (Arifin et al., 2020; Arya Wulandari et al., 2018) and SCTS (Fadillah et al., 2018; Noer, 2018) on mathematics and physics learning. However, no research has been found that explicitly describes the effect of the GDL model on SCU and SCTS on the solubility and solubility product subject matter. The results of this study have implications for learning science, especially chemistry learning in the current learning materials or similar characteristics learning materials to facilitate SCU and SCTS through problem-oriented interventions, analysis, evaluation, and reflection. These interventions have long been claimed to be the core and important activities in active learning for higher-order thinking skills teaching (G. P. Thomas, 2012; Zohar \& Barzilai, 2013).

\section{CONCLUSION}

This study has achieved the research objectives and concluded that the use of the GDL model had a significant effect $(\mathrm{p}<0.05)$ on SCU and SCTS on the solubility and solubility product subject matter. The mean score of the experimental group was better than the control group, both in SCU (mean= 81.51 vs. mean $=72.81$ ) and SCTS $($ mean $=70.46$ vs. mean $=58.43)$.

\section{RECOMMENDATION}

Some recommendations that need to be considered for further research based on the findings of the current study are (1) the implementation of the GDL model in the first stage (stimulation), which is carried out through the presentation of images, questions, and material concepts to stimulate students' initial knowledge. At this stage, students tend to take a relatively long time, so it is essential to be considered in choosing the form of presentation, choosing concepts and presentations in a systematic, easy to understand, contextual way, and using words or sentences that are easy to understand; (2) in the second stage (problem identification), many students experience difficulties in formulating problems and formulating hypotheses, so that it is important to pay more attention to these process skills; and (3) at the stage of conducting the experiment, students record the concept according to the observations in the form of numbers (numeric). Students have difficulty conducting data analysis and verification, so simple questions that lead to activities to find the relationship between observations and supporting concepts to make it easier for students to carry out the verification stage on the GDL model need further research.

\section{ACKNOWLEDGMENT}

This research received no specific grant from any funding agency in the public, commercial, or not for profit sectors. 


\section{REFERENCES}

Adnyana, G. P. (2012). Keterampilan Berpikir Kritis dan Pemahaman Konsep Siswa pada Model Siklus Belajar Hipotetis Deduktif. Jurnal Pendidikan Dan Pengajaran, 45(3), Article 3. https:/ / doi.org/10.23887/jppundiksha.v45i3.1833

Aikenhead, G. S. (2003). Chemistry and physics instruction: Integration, ideologies, and choices. Chem. Educ. Res. Pract., 4(2), 115-130. https:// doi.org/10.1039/B2RP90041F

Andayani, Y., Zulkarnain, Z., \& Hadisaputra, S. (2020). Promoting critical thinking skills of chemistry learning students using preparing doing concluding (PDC) learning models. Journal of Physics: Conference Series, 1521(4), 042116. https:// doi.org/10.1088/1742-6596/1521/4/042116

Anderson, L. W., \& Krathwohl, D. R. (Eds.). (2001). A taxonomy for learning, teaching, and assessing: A revision of Bloom's taxonomy of educational objectives (Complete ed). Longman.

Arends, R. (2012). Learning to teach (9th ed). McGraw-Hill.

Arifin, S., Wahyudin, W., \& Herman, T. (2020). The effects of contextual group guided discovery learning on students' mathematical understanding and reasoning. Jurnal Prima Edukasia, 8(2), 106-114. https:/ / doi.org/10.21831/jpe.v8i2.33059

Arsal, Z. (2017). The impact of inquiry-based learning on the critical thinking dispositions of pre-service science teachers. International Journal of Science Education, 39(10), 1326-1338. https:/ / doi.org/10.1080/09500693.2017.1329564

Arya Wulandari, I. G. A. P., Sa'dijah, C., As'ari, A. R., \& Rahardjo, S. (2018). Modified Guided Discovery Model: A conceptual Framework for Designing Learning Model Using Guided Discovery to Promote Student's Analytical Thinking Skills. Journal of Physics: Conference Series, 1028, 012153. https:/ / doi.org/10.1088/1742-6596/1028/1/012153

Asy'ari, M., Fitriani, H., Zubaidah, S., \& Mahanal, S. (2019). The Science Process Skills of Prospective Biology Teachers in Plant Cell Material Based on Gender. International Journal of Emerging Technologies in Learning (IJET), 14(19), 168. https:/ / doi.org/10.3991/ijet.v14i19.11208

Asy'ari, M., Hidayat, S., \& Muhali, M. (2019). Prototipe buku ajar fisika dasar reflektifintegratif berbasis problem solving untuk meningkatkan pengetahuan metakognisi. Jurnal Inovasi Pendidikan IPA, 5(2). https:// doi.org/10.21831/jipi.v5i2.27089

Asy'ari, M., Ikhsan, M., \& Muhali, M. (2019). The Effectiveness of Inquiry Learning Model in Improving Prospective Teachers' Metacognition Knowledge and Metacognition Awareness. International Journal of Instruction, 12(2), 455-470. https:// doi.org/10.29333/iji.2019.12229a

Asy'ari, M., Prayogi, S., Mirawati, B., Syarifuddin, Hunaepi, Syahrir, \& Suhirman. (2021). Development of physics learning tools based on inquiry to increase creative thinking skills. Journal of Physics: Conference Series, 1816(1), 012094. https:// doi.org/10.1088/1742-6596/1816/1/012094

Ayodele, A. A., \& Nasiru, O. I. (2021). Effect of guided-discovery technique on Colleges of Education Social Studies students' learning outcome. Journal of Education and Learning (EduLearn), 15(3), 390-396. https:/ / doi.org/10.11591/edulearn.v15i3.20300

Bisson, M.-J., Gilmore, C., Inglis, M., \& Jones, I. (2016). Measuring Conceptual Understanding Using Comparative Judgement. International Journal of Research 
in Undergraduate Mathematics Education, 2(2), 141-164. https:/ / doi.org/10.1007/s40753-016-0024-3

Borich, G. D. (2016). Observation Skills for Effective Teaching: Research-Based Practice (0 ed.). Routledge. https:/ / doi.org/10.4324/9781315633206

Cardellini, L. (2012). Chemistry: Why the Subject is Difficult? Educación Química, 23, 305-310. https:/ / doi.org/10.1016/S0187-893X(17)30158-1

Crooks, N. M., \& Alibali, M. W. (2014). Defining and measuring conceptual knowledge in mathematics. Developmental Review, 34(4), 344-377. https:// doi.org/10.1016/j.dr.2014.10.001

Demirhan, E., \& Köklükaya, A. N. (2014). The Critical Thinking Dispositions of Prospective Science Teachers. Procedia - Social and Behavioral Sciences, 116, 15511555. https:/ / doi.org/10.1016/j.sbspro.2014.01.433

Eggen, P. D., \& Kauchak, D. P. (2012). Strategies and models for teachers: Teaching content and thinking skills (6th ed). Pearson.

Ennis, R. H. (2011). The nature of critical thinking: An outline of critical thinking dispositions and abilities. Inquiry: Critical Thinking Across the Disciplines, 26(2), 1-8. https://doi.org/10.5840/inquiryctnews201126214

Ennis, R. H. (2018). Critical Thinking Across the Curriculum: A Vision. Topoi, 37(1), 165-184. https:/ / doi.org/10.1007/s11245-016-9401-4

Facione, P. A. (1990). Critical Thinking: A Statement of Expert Consensus for Purposes of Educational Assessment and Instruction. Research Findings and Recommendations. https:// eric.ed.gov/?id=ED315423

Facione, P. A. (2020). Critical Thinking: What It Is and Why It Counts. Measured Reasons LCC. content/uploads/ia/pdf/whatwhy.pdf

https://www.insightassessment.com/wp-

Fadillah, A., Yennita, Y., \& Sahal, M. (2018). The application of guided discovery learning model to improve students' critical thingking ability at the eighth grade students' of MTs Al-Huda Pekanbaru. Jurnal Geliga Sains: Jurnal Pendidikan Fisika, 6(1), 39. https:/ / doi.org/10.31258/jgs.6.1.39-46

Fischer, F., Kollar, I., Ufer, S., Sodian, B., Hussmann, H., Pekrun, R., Neuhaus, B., Dorner, B., Pankofer, S., Fischer, M., Strijbos, J.-W., Heene, M., \& Eberle, J. (2014). Scientific Reasoning and Argumentation: Advancing an Interdisciplinary Research Agenda in Education. Frontline Learning Research, 2(3), 28-45. https:/ / doi.org/10.14786/flr.v2i2.96

Fitriani, H., Asy'ari, M., Zubaidah, S., \& Mahanal, S. (2019). Exploring the Prospective Teachers' Critical Thinking and Critical Analysis Skills. Jurnal Pendidikan IPA Indonesia, 8(3), Article 3. https:/ / doi.org/10.15294/jpii.v8i3.19434

Fraenkel, J. R., Wallen, N. E., \& Hyun, H. H. (2012). How to design and evaluate research in education (8th ed). McGraw-Hill Humanities/Social Sciences/Languages.

Freire, M., Talanquer, V., \& Amaral, E. (2019). Conceptual profile of chemistry: A framework for enriching thinking and action in chemistry education. International Journal of Science Education, 41(5), 674-692. https:/ / doi.org/10.1080/09500693.2019.1578001

Furtak, E. M., Seidel, T., Iverson, H., \& Briggs, D. C. (2012). Experimental and QuasiExperimental Studies of Inquiry-Based Science Teaching: A Meta-Analysis. Review of Educational Research, 82(3), 300-329. https:// doi.org/10.3102/0034654312457206 
Gelder, T. van. (2005). Teaching Critical Thinking: Some Lessons From Cognitive Science. College Teaching, 53(1), 41-48. https:/ / doi.org/10.3200/CTCH.53.1.4148

Großmann, N., \& Wilde, M. (2019). Experimentation in biology lessons: Guided discovery through incremental scaffolds. International Journal of Science Education, 41(6), 759-781. https:// doi.org/10.1080/09500693.2019.1579392

Hiebert, J., \& Grouws, D. A. (2007). The Effects of Classroom Mathematics Teaching on Students' Learning. In F. K. Lester (Ed.), Second Handbook of Research on Mathematics Teaching and Learning (pp.371-404). Information Age Pub.

Hmelo-Silver, C. E., Duncan, R. G., \& Chinn, C. A. (2007). Scaffolding and Achievement in Problem-Based and Inquiry Learning: A Response to Kirschner, Sweller, and Clark (2006). Educational Psychologist, 42(2), 99-107. https:/ / doi.org/10.1080/00461520701263368

Holme, T. A., Luxford, C. J., \& Brandriet, A. (2015). Defining Conceptual Understanding in General Chemistry. Journal of Chemical Education, 92(9), 14771483. https://doi.org/10.1021/acs.jchemed.5b00218

Hoy, A. W. (2013). Educational psychology (12th ed). Pearson.

Janssen, F. J. J. M., Westbroek, H. B., \& van Driel, J. H. (2014). How to make guided discovery learning practical for student teachers. Instructional Science, 42(1), 6790. https://doi.org/10.1007/s11251-013-9296-z

Kalyuga, S. (2013). Enhancing transfer by learning generalized domain knowledge structures. European Journal of Psychology of Education, 28(4), 1477-1493. https:/ / doi.org/10.1007/s10212-013-0176-3

Kemendikbud. (2018). Peraturan Menteri Pendidikan dan Kebudayaan Republik Indonesia Nomor $37 \quad$ Tahun $2018 . \quad$ Kemendikbud. https:/ /jdih.kemdikbud.go.id/arsip/Permendikbud\%20Nomor\%2037\%20Ta hun\%202018.pdf

Kibirige, I., \& Maake, R. M. (2021). The effect of guided discovery instructional strategy on grade nine learners' performance in chemical reactions in Mankweng circuit, South Africa. Journal of Technology and Science Education, 11(2), 569. https:/ / doi.org/10.3926/jotse.1295

Kwan, Y. W., \& Wong, A. F. L. (2015). Effects of the constructivist learning environment on students' critical thinking ability: Cognitive and motivational variables as mediators. International Journal of Educational Research, 70, 68-79. https:// doi.org/10.1016/j.ijer.2015.02.006

Lay, A.-N., \& Osman, K. (2018). Developing 21st Century Chemistry Learning through Designing Digital Games. Journal of Education in Science, Environment and Health, 4(1), 81-92.

Lee, J. S. Y., \& Yeung, C. Y. (2021). Assisted discovery-based learning for literature studies. Innovations in Education and Teaching International, 1-12. https:// doi.org/10.1080/14703297.2021.1916567

Lilienfeld, S. O., Ammirati, R., \& David, M. (2012). Distinguishing science from pseudoscience in school psychology: Science and scientific thinking as safeguards against human error. Journal of School Psychology, 50(1), 7-36. https:/ / doi.org/10.1016/j.jsp.2011.09.006

Moreno, R. (2010). Educational psychology. John Wiley \& Sons. 
Muhali, M. (2019). Pembelajaran Inovatif Abad Ke-21. Jurnal Penelitian Dan Pengkajian Ilmu Pendidikan: E-Saintika, 3(2), 25. https://doi.org/10.36312/esaintika.v3i2.126

Muhali, M. (2021). Pengaruh Implementasi Model Creative Problem Solving terhadap Peningkatan Kemampuan Pemecahan Masalah, Keterampilan Proses Sains, dan Kesadaran Metakognisi Peserta Didik. Lensa: Jurnal Kependidikan Fisika, 9(1), 45-57. https:// doi.org/10.33394/j-1kf.v9i1.4261

Muhali, M., Sukaisih, R., \& Asy'ari, M. (2020). Implementasi model reflectivemetacognitive learning untuk meningkatkan kemampuan berpikir kritis, keterampilan metakognisi dan kesadaran metakognisi. Empiricism Journal, 1(2), 75-95. https:// doi.org/10.36312/ ej.v1i2.337

Muhali, M., Yuanita, L., \& Ibrahim, M. (2019). The Validity and Effectiveness of the Reflective-Metacognitive Learning Model to Improve Students' Metacognition Ability in Indonesia. Malaysian Journal of Learning and Instruction, 16(2), 33-74. https:/ / doi.org/10.32890/mjli2019.16.2.2

Muliyani, R. (2018). Signifikansi discovery learning vs guided discovery learning terhadap peningkatan pemahaman konsep. Gravity: Jurnal Ilmiah Penelitian Dan Pembelajaran Fisika, 4(1). https:/ / doi.org/10.30870/gravity.v4i1.3118

Murphy, C., Abu-Tineh, A., Calder, N., \& Mansour, N. (2021). Teachers and students' views prior to introducing inquiry-based learning in Qatari science and mathematics classrooms. Teaching and Teacher Education, 104, 103367. https:/ / doi.org/10.1016/j.tate.2021.103367

National Research Council (Ed.). (2012). A framework for K-12 science education: Practices, crosscutting concepts, and core ideas. The National Academies Press.

NCATE. (2008). Professional Standards for the Accreditation of Teacher Preparation Institutions. In National Council for Accreditation of Teacher Education (NJ3). National Council for Accreditation of Teacher Education. https:/ / eric.ed.gov/ ?id=ED502043

Nieveen, N. (1999). Prototyping to Reach Product Quality. In J. van den Akker, R. M. Branch, K. Gustafson, N. Nieveen, \& T. Plomp (Eds.), Design Approaches and Tools in Education and Training (pp. 125-135). Springer Netherlands. https:// doi.org/10.1007/978-94-011-4255-7_10

Noer, S. H. (2018). Guided discovery model: An alternative to enhance students' critical thinking skills and critical thinking dispositions. Jurnal Riset Pendidikan Matematika, 5(1), 108-115. https://doi.org/10.21831/jrpm.v5i1.16809

O'Dwyer, L. M., Wang, Y., \& Shields, K. A. (2015). Teaching for conceptual understanding: A cross-national comparison of the relationship between teachers' instructional practices and student achievement in mathematics. Large-Scale Assessments in Education, 3(1), 1. https://doi.org/10.1186/s40536014-0011-6

Prayogi, S., \& Verawati, N. N. S. P. (2020). The Effect of Conflict Cognitive Strategy in Inquiry-based Learning on Preservice Teachers' Critical Thinking Ability. Journal of Educational, Cultural and Psychological Studies (ECPS Journal), 0(21), 2741. https://doi.org/10.7358/ecps-2020-021-pray

Prayogi, S., Yuanita, L., \& Wasis. (2018). Critical Inquiry Based Learning: A Model of Learning to Promote Critical Thinking Among Prospective Teachers of Physic. Journal of Turkish Science Education, 15(1), 43-56. 
Preston, L., Harvie, K., \& Wallace, H. (2015). Inquiry-based Learning in Teacher Education: A Primary Humanities Example. Australian Journal of Teacher Education, 40(12). https://doi.org/10.14221/ajte.2015v40n12.6

Ribeiro, M. A. P., \& Pereira, D. C. (2013). Constitutive Pluralism of Chemistry: Thought Planning, Curriculum, Epistemological and Didactic Orientations. Science E Education, 22(7), 1809-1837. https://doi.org/10.1007/s11191-0119434-4

Rittle-Johnson, B., Schneider, M., \& Star, J. R. (2015). Not a One-Way Street: Bidirectional Relations Between Procedural and Conceptual Knowledge of Mathematics. Educational Psychology Review, 27(4), 587-597. https:// doi.org/10.1007/s10648-015-9302-x

Sari, R. Y., \& Cahyo, H. N. (2020). Effectivity of Guided Discovery Learning with Concept Mapping to improve conceptual understanding in endocrine system material for grade XI science class. Journal of Physics: Conference Series, 1440(1), 012077. https:/ / doi.org/10.1088/1742-6596/1440/1/012077

Sari, U., \& Güven, G. B. (2013). The Effect of Interactive Whiteboard Supported Inquiry-Based Learning on Achievement and Motivation in Physics and Views of Prospective Teachers Toward the Instruction. Necatibey Faculty of Education Electronic Journal of Science and Mathematics Education, 7(2), 110-143. https:/ / doi.org/10.12973/nefmed204

Schmaltz, R. M., Jansen, E., \& Wenckowski, N. (2017). Redefining Critical Thinking: Teaching Students to Think like Scientists. Frontiers in Psychology, 8, 1-4. https://doi.org/10.3389/fpsyg.2017.00459

Schunk, D. H. (2012). Learning theories: An educational perspective (6th ed). Pearson.

Scriven, M., \& Paul, R. M. (1987). Defining Critical Thinking. http://www.criticalthinking.org/pages/defining-critical-thinking/766

Shamsuddeen, A., \& Amina, H. (2016). Instructional Methods and Students' End of Term Achievement in Biology in Selected Secondary Schools in Sokoto Metropolis, Sokoto State Nigeria. Journal of Education and Practice, 7(32), 198.

Shieh, C.-J., \& Yu, L. (2016). A Study on Information Technology Integrated Guided Discovery Instruction towards Students' Learning Achievement and Learning Retention. EURASIA Journal of Mathematics, Science and Technology Education, 12(4). https:// doi.org/10.12973/ eurasia.2015.1554a

Sudria, I. B. N., Redhana, I. W., \& Samiasih, L. (2011). Pengaruh pembelajaran interaktif laju reaksi berbantuan komputer terhadap hasil belajar siswa. Jurnal Pendidikan Dan Pengajaran, 44(1), Article 1. https:// doi.org/10.23887/jppundiksha.v44i1.135

Suhirman, Prayogi, S., \& Asy'ari, M. (2021). Problem-Based Learning with CharacterEmphasis and Naturalist Intelligence: Examining Students Critical Thinking and Curiosity. International Journal of Instruction, 14(2), 217-232.

Suparini, S., Rusdi, R., \& Ristanto, R. H. (2020). Guided discovery-blended learning (GDBL) for critical thinking skill empowerment: A learning strategy in human excretory system. Biosfer, 13(2), 266-279. https:/ / doi.org/10.21009/biosferjpb.v13n2.266-279

Thaiposri, P., \& Wannapiroon, P. (2015). Enhancing Students' Critical Thinking Skills through Teaching and Learning by Inquiry-based Learning Activities Using Social Network and Cloud Computing. Procedia - Social and Behavioral Sciences, 174, 2137-2144. https:/ / doi.org/10.1016/j.sbspro.2015.02.013 
Thomas, G. P. (2012). Metacognition in science education: Past, present and future considerations. In B. Fraser, K. Tobin, \& C. J. McRobbie (Eds.), Second International Handbook of Science Education. Springer Netherlands. https:/ / doi.org/10.1007/978-1-4020-9041-7

Thomas, T. A. (2011). Developing First YearStudents' Critical Thinking Skills. Asian Social Science, 7(4), p26. https://doi.org/10.5539/ass.v7n4p26

Treagust, D., Chittleborough, G., \& Mamiala, T. (2003). The role of submicroscopic and symbolic representations in chemical explanations. International Journal of Science Education, 25(11), 1353-1368. https:/ / doi.org/10.1080/0950069032000070306

Trninic, D. (2018). Instruction, repetition, discovery: Restoring the historical educational role of practice. Instructional Science, 46(1), 133-153. https:/ / doi.org/10.1007/s11251-017-9443-z

Tsaparlis, G. (2018). Challenges, Barriers, and Achievements in Chemistry Education: The Case of Greece. In C. Cox \& W. E. Schatzberg (Eds.), ACS Symposium Series (Vol. 1293, pp. 93-110). American Chemical Society. https:/ / doi.org/10.1021/bk-2018-1293.ch007

van der Graaf, J., Segers, E., \& de Jong, T. (2020). Fostering integration of informational texts and virtual labs during inquiry-based learning. Contemporary Educational Psychology, 62, 1-15. https:/ / doi.org/10.1016/j.cedpsych.2020.101890

Vygotsky, L. S. (1981). Mind in society: The development of higher psychological processes (Nachdr.). Harvard Univ. Press.

Yerizon, Y., Putra, A. A., \& Subhan, M. (2018). Mathematics Learning Instructional Development based on Discovery Learning for Students with Intrapersonal and Interpersonal Intelligence (Preliminary Research Stage). International Electronic Journal of Mathematics Education, 13(3). https:// doi.org/10.12973/iejme/2701

Yuliani, K., \& Saragih, S. (2015). The Development of Learning Devices Based Guided Discovery Model to Improve Understanding Concept and Critical Thinking Mathematically Ability of Students at Islamic Junior High School of Medan. Journal of Education and Practice, 6(24), 116-128.

ŽivkoviL, S. (2016). A Model of Critical Thinking as an Important Attribute for Success in the 21st Century. Procedia - Social and Behavioral Sciences, 232, 102-108. https:/ / doi.org/10.1016/j.sbspro.2016.10.034

Zohar, A., \& Barzilai, S. (2013). A review of research on metacognition in science education: Current and future directions. Studies in Science Education, 49(2), 121-169. https:/ / doi.org/10.1080/03057267.2013.847261 